\title{
ПОРІВНЯЛЬНИЙ АНАЛІЗ ПОДАТКОВИХ СИСТЕМ ЗАРУБІЖНИХ КРАЇ̈ ТА УКРАЇНИ
}

\section{COMPARATIVE ANALYSIS OF TAX SYSTEMS OF FOREIGN COUNTRIES AND UKRAINE}

\author{
Мережко Світлана Петрівна \\ студентка, \\ ДВНЗ «Донецький національний технічний університет» \\ ORCID: https://orcid.org/0000-0002-5157-3250 \\ Ушолік Наталя Романівна \\ студентка, \\ ДВНЗ «Донецький національний технічний університет» \\ ORCID: https://orcid.org/0000-0002-2218-5005 \\ Лизунова Олена Миколаївна \\ доктор економічних наук, профресор, \\ ДВНЗ «Донецький національний технічний університет» \\ ORCID: https://orcid.org/ 0000-0002-0083-4422
Merezhko Svitlana, Usholik Natalia, Olena Lyzunova
SEIU «Donetsk National Technical University»

\begin{abstract}
У статті розглянуто особливості побудови податкових систем в Україні та в зарубіжних країнах. Досліджено питому вагу податкових платежів у структурі валового внутрішнього продукту країн ЄС, США, Японії та України Розглянуто сутність основних податків: податок на додану вартість, податок на доходи фрізичних осіб, податок на прибуток підприємств тощо. Проаналізовані максимальні ставки податків в Україні та в інших країнах. Доведено, що основне завдання при формуванні податкових систем полягає в оптимізації потреб у податкових надходженнях із можливостями їхнього отримання. Охарактеризовано принцип простоти адміністрування, який полягає в мінімізації витрат на сплату податків, простоті їх нарахування, зменшення часу на їх контроль. Наведені особливості принципу соціальної направленості податкової системи спрямованого на вирішення соціальних проблем. Зроблено оцінку податкового тиску в Україні і інших країнах світу. Проаналізовано загальну кількість податків в різних країнах. Виявлено, що в Україні на відміну від зарубіжних країн, в структурі податкових надходжень переважають непрямі податки. Досліджено позитивні та негативні характеристики податкової системи України. Виявлено, що податкові системи різних країн складалися під впливом різних економічних, політичних та соціальних умов Висвітлено фундаментальні принципи оптимальної податкової системи. Виявлено, що існує два підходи до оподаткування доходів: пряма і прогресивна система оподаткування. Пряма шкала оподаткування не відповідає принципу соціальної рівності, оскільки малозабезпечені та заможні верстви населення сплачують у бюджет однаковий відсоток свого доходу Прогресивна система оподаткування застосовується в провідних країнах світу. Доведено: в Україні оптимальна кількість податків на фроні країн $€ C$, що свідчить про умовну легкість їх адміністрування. В нашій країні переважну частину надходжень до бюджету складають непрямі податки, тобто податки, що сплачуються кінцевим споживачем. Доведено, що процес отримання податків треба організувати таким чином, аби він більшою мірою сприяв реалізації політики кон'юнктури та зайнятості шляхом накопичення фрінансових ресурсів. Виявлено напрями підвищення есрективності податкових систем. Зроблено висновки, що податкова система України є проблемною.

Ключові слова: оподаткування, податкова система, податкова політика, бюджетні надходження, податковий тиск, податкова конкуренція, платник податків.
\end{abstract}

В статье рассмотрены особенности построения налоговых систем в Украине и в зарубежных странах. Исследован удельный вес налоговых платежей в структуре валового внутреннего продукта стран ЕС, США, Японии и Украины. Рассмотрена сущность основных налогов: налога на добавленную стоимость, налога на доходы фризических лиц, налога на прибыль предприятий и тому подобное. Проанализированы максимальные ставки налогов в Украине и в других странах. Доказано, что основная задача при орормировании налоговых 
систем заключается в оптимизации потребностей в налоговых поступлениях с возможностями их получения. Охарактеризован принцип простоты администрирования, который заключается в минимизации расходов на уплату налогов, простоте их начисления, уменьшении времени на их контроль. Приведены особенности принципа социальной направленности налоговой системы направленного на решение социальных проблем. Сделана оценка налогового давления в Украине и других странах мира. Проанализировано общее количество налогов в разных странах. Обнаружено, что в Украине в отличие от зарубежных стран, в структуре налоговых поступлений преобладают косвенные налоги. Исследованы положительные и отрицательные характеристики налоговой системы Украины. Выявлено, что налоговые системы разных стран складывались под влиянием различных экономических, политических и социальных условий. Освещены фрундаментальные принципы оптимальной налоговой системы. Выявлено, что существует два подхода к налогообложению доходов: прямая и прогрессивная система налогообложения. Прямая шкала налогообложения не соответствует принципу социального равенства, поскольку малообеспеченные и зажиточные слои населения платят в бюджет одинаковый процент своего дохода Прогрессивная система налогообложения применяется в ведущих странах мира. Доказано: в Украине оптимальное количество налогов на фроне стран ЕС, что свидетельствует об условной легкости их администрирования. В нашей стране подавляющую часть поступлений в бюджет составляют косвенные налоги, то есть налоги, уплачиваемые конечным потребителем. Доказано, что процесс получения налогов надо организовать таким образом, чтобы он в большей степени способствовал реализации политики конъюнктуры и занятости путем накопления фринансовых ресурсов. Выявлены направления повышения эфрфективности налоговых систем. Сделаны выводы, что налоговая система Украины является проблемной.

Ключевые слова: налогообложение, налоговая система, налоговая политика, бюджетные поступления, налоговое давление, налоговая конкуренция, налогоплательщик.

The article considers the peculiarities of the construction of tax systems in Ukraine and in foreign countries. The specific weight of tax payments in the structure of gross domestic product of EU countries, USA, Japan and Ukraine is investigated. The essence of basic taxes: the value-added tax, the personal income tax, the corporate income tax and so on is considered. The maximum rates of taxes in Ukraine and in other countries are analyzed. It is proved that the basic problem in formation of tax systems consists in optimization of requirements in tax receipts with possibilities of their reception. The principle of simplicity of administration which consists in minimization of expenses for payment of taxes, simplicity of their calculation, reduction of time for their control is characterized. The features of the principle of social orientation of tax system aimed at solving social problems are given. The estimation of tax pressure in Ukraine and other countries of the world is made. The total number of taxes in different countries was analyzed. It was found that in Ukraine unlike in foreign countries indirect taxes prevail in the structure of tax revenues. The positive and negative characteristics of the tax system of Ukraine were studied. It was found that the tax systems of different countries were formed under the influence of different economic, political and social conditions. The fundamental principles of the optimal tax system are highlighted. It has been revealed that there are two approaches to income taxation: direct and progressive systems of taxation. The direct taxation scale does not correspond to the principle of social equality because low-income and well-to-do people pay the same percentage of their income to the budget Progressive taxation system is applied in the leading countries of the world. It has been proved that Ukraine has an optimal number of taxes in comparison with EU countries, which indicates that they are relatively easy to administer. In our country, the overwhelming majority of the budget revenues are indirect taxes, that is, taxes paid by the final consumer. It is proved that the process of tax collection should be organized in such a way as to contribute more to the realization of the policy of conjuncture and employment by accumulating financial resources. Directions for improving the efficiency of tax systems are identified. Conclusions were drawn that the tax system of Ukraine is a problematic one.

Keywords: taxation, tax system, tax policy, budget revenue, tax pressure, tax competition, taxpayer.

Постановка проблеми. Податкова система $€$ однією 3 найважливіших елементів регулювання економічних та соціальних процесів країни. Вивчення податкових систем зарубіжних країн набуває особливої актуальності, тому що податкова конкуренція між країнами виступає однією 3 глобальних сучасних проблем міжнародного рівня.

Аналіз останніх досліджень і публікацій. Дослідженням даного питання займались такі науковці, як: П. Мельник, Т. Волинець, Ю. Козак, В. Козаченко, О. Лютий, Л. Біла, Л. Лисак, А. Гречко та інші. Проте, на сьогодні залишаються невирішеними такі питання, як дотримання соціальної направленості оподаткування, адміністрування податків, росту податкової культури населення.

Виділення невирішених раніше частин загальної проблеми. Ефективна податкова система гарантує стабільність економічного розвитку держави, адже саме податкова система забезпечує постійне надходження кошів до державного бюджету та повинна сприяти розвитку діяльності як юридичних осіб, так і приватних підприємців і в той же час задовольняти потреби держави. Однак, одним із напрямків вдосконалення податкової системи нашої держави $€$ ії̈ порівняння з розвиненими зарубіжними країнами. 
Формулювання цілей статті. Метою дослідження $€$ порівняння податкових систем нашої країни та зарубіжних держав, виявлення їх особливостей, переваг та недоліків, визначення принципів побудови оптимальної податкової системи.

Виклад основного матеріалу дослідження. В умовах розвинутих ринкових відносин податкова система $є$ одним із важливих елементів регулювання економічних і соціальних процесів у державі. Головне завдання при срормуванні податкових систем полягає в оптимізації потреб у податкових надходженнях із можливостями їх отримання. В Україні питома вага податкових платежів у структурі валового внутрішнього продукту нижча, ніж в Японії чи країнах $€ С$, але більша, ніж в США. На рисунку 1 грасрічно представлена питома вага податків у структурі ВВП США, країн $€ С$, Японії та України.

3 рис. 1 можна зробити висновок, що в Україні відносно невеликий податковий тиск $27,3 \%$, менший лише в США $26,9 \%$, в той час у країнах ЄС податковий тиск у середньому склав 39,3\%.

Існує два підходи до оподаткування доходів:

1) пряма шкала: податок розраховується за єдиною ставкою незалежно від рівня доходу. Пряма шкала оподаткування не враховує принцип соціальної рівності: малозабезпечені та заможні верстви населення сплачують однаковий відсоток з доходу (Україна, Росія, Грузія, Болгарія);

2) прогресивна шкала спрямована на збільшенні податкових ставок при збільшенні доходу (Франція, США, Німеччині, Великобританія, Нідерланди) [2, с. 32].

Розглянемо принципи оптимальної податкової політики держави.
- принцип простоти: мінімізація витрат на сплату податків, простота їх нарахування, зменшення часу на адміністрування, зручність;

- принцип соціальної справедливості: податковій системі необхідно прагнути до вирішення соціальних проблем;

- принцип економічної ефективності: відповідність ставок податків економічному розвитку держави.

Проаналізуємо кількість податків в різних країнах. В нашій країні законодавством затверджено 11 податків та зборів: (7 державних та 4 місцевих), в Японії - 55 (25 державних та 30 місцевих), в Великобританії - 8, Італії - 15, Німеччині - 16, Франції - 7, Нідерландах - 9, Португалії - 8, Іспанії - 8, податків. Тобто, робимо висновок, що в нашій країні оптимальна кількість податків порівняно 3 іншими країнами світу.

В Україні більшу частину надходжень до бюджету складають непрямі податки, а саме податок на додану вартість та акцизний податок. Так, у 2021 році ПДВ склав 50,69\% усіх бюджетних надходжень, акцизний податок $15,64 \%$, ПДФО - 21,33\%, податок на прибуток підприємств - 9,25\%. У країнах ЄС та США більшість надходжень до бюджету складають прямі податки.

Проаналізуємо ставки основних податків в нашій країні та в інших країнах (табл. 1).

Взагалі, ставки основних податків в Україні $€$ нижчими ніж в інших країнах. Україна має найнижчі податкові ставки по трьох основним податкам серед країн Європи, які аналізуються. На другому місці розмістилась Польща, на третьому - Німеччина, четвертому - Іспанія, п'ятому - Нідерланди. Робимо висновок, в нашій країні найнижчі максимальні податкові ставки в порівнянні з країнами Європи.

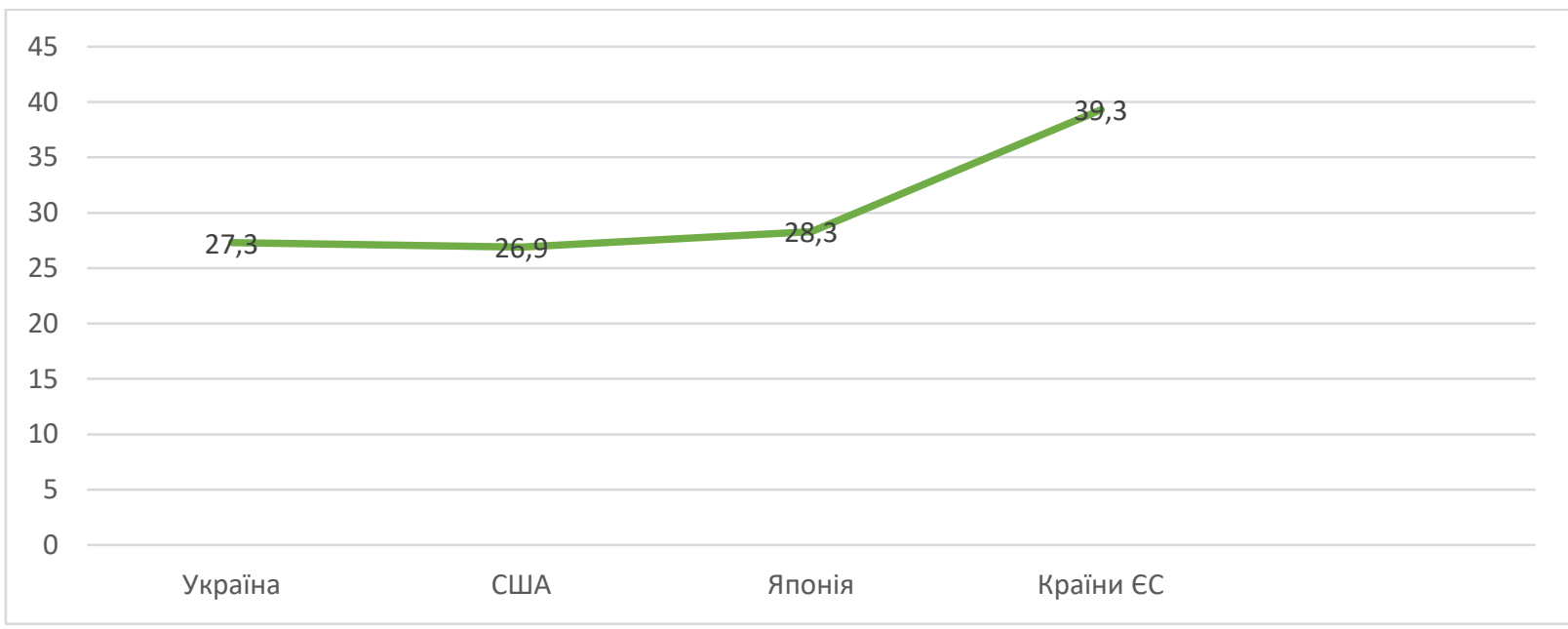

Рис. 1. Питома вага податків у структурі ВВП України, США, Японії, країн ЄС [1] 
Ставки основних в Україні та інших країнах

\begin{tabular}{|l|c|c|c|c|c|c|c|}
\hline \multirow{2}{*}{ Країна } & \multicolumn{2}{|c|}{ Ставка пдВ } & \multicolumn{2}{c|}{ Ставка ПдФо } & \multicolumn{2}{c|}{$\begin{array}{c}\text { Ставка податку } \\
\text { на прибуток }\end{array}$} & $\begin{array}{c}\text { Загальний } \\
\text { рейтинг країни, } \\
\text { місце }\end{array}$ \\
\cline { 2 - 7 } & $\%$ & місце & $\%$ & місце & $\%$ & місце & 1 \\
\hline Україна & 20 & 2 & 18 & 1 & 18 & 1 & 3 \\
\hline Німеччина & 19 & 1 & 47,5 & 6 & 29,8 & 4 & 4 \\
\hline Іспанія & 21 & 3 & 45 & 4 & 30 & 5 & 7 \\
\hline Італія & 22 & 4 & 45,6 & 5 & 31,4 & 6 & 6 \\
\hline Франція & 20 & 2 & 45 & 4 & 34,4 & 8 & 5 \\
\hline Нідерланди & 21 & 3 & 52 & 7 & 25,5 & 3 & 8 \\
\hline Португалія & 23 & 5 & 42 & 3 & 36 & 9 & 9 \\
\hline Бельгія & 21 & 3 & 53,7 & 8 & 34 & 7 & 2 \\
\hline Польща & 23 & 5 & 32 & 2 & 19 & 2 & \\
\hline
\end{tabular}

Головним напрямом підвищення ефрективності податкової системи є запровадження оптимальних принципів оподаткування. Незважаючи на те, що ці заходи мають специсрічні риси для кожної країни, в цілому вони спрямовані на ефрективне оподаткування та досягнення соціальної справедливості.

Висновки. Порівнявши податкову систему нашої країни з більш розвиненими країнами, дійшли висновку - ідеальної податкової системи не існує, але є системи наближені до ідеалу в таких країнах, як Німеччина, США, Італія. 3 позитивних характеристик податко- вої системи України можна виділити відносно невеликий податковий тиск порівняно 3 країнами Європи та найнижчі ставки основних податків. На жаль, негативних характеристик набагато більше, ніж позитивних, серед них переважна доля податкових надходжень від непрямих податків над прямими, пряма система оподаткування, значні розбіжності в бухгалтерському та податковому обліках, слабка система адміністрування. оподаткування повинен досягати рівновага між потребами наповнення бюджетів та дотримання соціальної справедливості в суспільстві.

\section{СПИСОК ВИКОРИСТАНИХ ДЖЕРЕЛ:}

1. Соколовська А.М. Податкова система держави: теорія та практика становлення : автореф. дис. д.е.н. 2018. $488 \mathrm{c}$.

2. Карлін М.І. Фінанси країн Європейського Союзу. Київ : Знання, 2017. 639 с.

3. Податковий кодекс України від 02.12.2010р. № 2755-VI / База даних інформаційно-правової системи «ЛІГА». URL: http//www.liga.net

4. Гречко А.В. Перспективи реформування податкової системи України в умовах євроінтеграції. Економіка та управління національним господарством. 2016. № 3. С. 60-70.

5. Презентація результатів дослідження на тему: «Сприйняття українцями ситуації в сфрері оподаткування України» / Український офіс міжнародного дослідницького агентства IFAK Institut. Червень, 2016 p. URL: http://www.ueff.org/\#!Податкова-панщина-лише-20-українців-вважають-існуючі-податкисправедливими/ cjds/575e8e470cf2d021c3fb4c96

6. Податки у світі: навіщо нам потрібні податки та як створити ефективну систему оподаткування? URL: http://www.visnuk.com.ua/uk/news/100016559-podatki-u-sviti-navischo-nam-potribni-podatki-ta-yak-stvoritiefektivnu-sistemu-opodatkuvannya

7. Гусейніков Ю. Досвід країн Євросоюзу в боротьбі з податковими злочинами / Україна-НАТО. Київ, 2018. № 3. C. 45.

\section{REFERENCES:}

1. Sokolovska A.M. (2018) Podatkova sistema derzhavi: teoriya ta praktika stanovlennya: avtoref. dis. d.e.n. 488 p.

2. Karlin M.I. (2017) Finansi krayin Yevropejskogo Soyuzu. Kyiv: Znannya, 639 p.

3. Podatkovij kodeks Ukrayini vid 02.12.2010 r. № 2755-VI / Baza danikh informaczijno-pravovoyi sistemi «LIGA». URL: http//www.liga.net 
4. Grechko A.V. (2016) Perspektivi reformuvannya podatkovoyi sistemi Ukrayini v umovakh yevrointegracziyi. Ekonomika ta upravlinnya naczionalnim gospodarstvom, no. 3, pp. 60-70.

5. Prezentacziya rezultativ doslidzhennya na temu: «Sprijnyattya ukrayinczyami situacziyi v sferi opodatkuvannya Ukrayini» / Ukrayinskij ofis mizhnarodnogo doslidniczkogo agentstva IFAK Institut. Cherven, 2016 r. URL:http://www.ueff.org/\#!Podatkova-panshhina-lishe-20-ukrayincziv-vvazhayut-isnuyuchi-podatkispravedlivimi/cjds/ 575e8e470cf2d021c3fb4c96

6. Podatki u sviti: navishho nam potribni podatki ta yak stvoriti efektivnu sistemu opodatkuvannya? URL: http://www.visnuk.com.ua/uk/news/100016559-podatki-u-sviti-navischo-nam-potribni-podatki-ta-yak-stvoritiefektivnu-sistemu-opodatkuvannya

7. Gusejnikov Yu. (2018) Dosvid krayin Yevrosoyuzu v borot bi z podatkovimi zlochinami / Ukrayina-NATO. Kyiv, no. 3, p. 45. 